\author{
ACTA MYCOLOGICA \\ Vol. 47 (2): 133-138 \\ 2012
}

\title{
Ecological characteristics of a Hungarian summer truffle (Tuber aestivum Vittad.) producing area
}

\author{
ANDREA CSORBAI GÓGÁN ${ }^{1}$, ZSÓFIA NAGY², ZOLTÁN DÉGI ${ }^{2}$, ISTVÁN BAGI ${ }^{3}$ \\ and JUDIT DIMÉNY ${ }^{1}$
}

\begin{abstract}
${ }^{1}$ Szent István University, Faculty of Agricultural and Environmental Sciences, Institute of Horticultural Technologies, Páter Károly str.1, H-2103, Gödöllő, gogan.andrea@mkk.szie.hu ${ }^{2}$ Nagykunság Forest and Timber Management Company, József Attila str. 34, H-5000 Szolnok

${ }^{3}$ Truffleminers Co. H-2335, Kinizsi str. 1, Taksony
\end{abstract}

Gógán A.Cs., Nagy Z., Dégi Z., Bagi I., Dimény J.: Ecological characteristics of a Hungarian summer truffle (Tuber aestivum Vittad.) producing area. Acta Mycol. 47 (2): 133-138, 2012.

Hungary has outstanding environment for natural truffle production in some regions including plain and hilly areas. The most famous of all the natural summer truffle (Tuber aestivum Vittad.) habitats is the commonly called Jászság region. This area is situated in the middle of Hungary, between river Danube and Tisza. The flatland area is basically covered by river alluviums with main soils of chernozems, fluvisols, solonchaks and arenosols. Climate of the region is typically continental: warm and dry summers and cold winters vary. The area is traditionally of agricultural use, although strong afforestation was made in the late 1950's. The English oak (Quercus robur L.) populations planted at that time gave a basis for current excellent truffle production. Nowadays the region has proved to be the best natural summer truffle (T. aestivum) producing area of Hungary with early season opening (June) and high quality truffles as early as August. In the research the best truffle producing forest blocks were selected for ecological investigation. Results of the detailed site description showed uniform climate characteristics and dominance of English oak (Q. robur) or mixed English oakTurkey oak (Quercus cerris L.) forests. Soil types revealed differences from earlier findings: dominance of gleysols and water affected chernozems was declared. Soil chemical parameters are in accordance with literature data: $\mathrm{pH}$, organic matter and active carbonate content of the examined soils fall within the range indicated as the requirement of T. aestivum.

Key words: Trufficulture, soil characteristics, climate, forest management 


\section{INTRODUCTION}

Consumption of truffles originates from ancient times in certain areas of the Mediterranean region. From medieval centuries, use of black truffles gained ground in other European countries, based primarily on French and Hungarian cookbooks of the period. Truffles have been originated from natural forests from hundreds years and in some countries are still the main resources of truffle harvest. Summer truffle (Tuber aestivum), referred also Burgundy truffle considered as the third most important one in Europe and probably the most common truffle of marketable species (Hall et al. 2007).It is a widespread truffle species in Europe.

Due to its wide tolerance toward ecological factors, it is common from Sweden to Spain, from the United Kingdom to Russia (Ceruti et al. 2003; Granetti et al. 2005; Tulasne 1851; Wedén, Danell 2001). In Central Europe Hungary plays an important role in the truffle market with considerable yield of T. aestivum (Gógán et al. 2007a). Due to its wide tolerance toward environmental factors, the species is widespread in the country (Bratek 2005). Soil parameters can limit its distribution to soils rich in organic matter with variable lime content and neutral or lightly basic $\mathrm{pH}$ (Gógán et al. 2007b; Bratek 2005, 2008).

\section{MATERIALS AND METHODS}

Study area description. According to forest management it is called as Tápió-Zagyva territory, referred to the main rivers of the region, however, Hungarian cadastral map refers the region Jászság area. In our study, due to practical reasons, we fitted region borders to the management territory of Nagykunság Forest and Timber Management Company, meaning a slight enlargement.

The lowland, flat area is covered by river alluvium, relief is characterised by river deposits. The area is often threatened by inland inundations; floodplains are regularly covered by river floods. Geological patterns is determined by Middle Miocene volcanic ash but rivers arriving from the north loaded fine sediments (mainly loam) to the surface in the Pleistocene resulted in moorlands and marshland in the area. Later 1-4 m deep loess and Holocene alluvial warp arrived to the area. In some areas sandy soils appear. The most common soil types are calcareous chernozem and fluvisols but solonchaks and arenosols also occur. Climate of the area is warm and dry with 2000 hours of annual sunshine and $10.2 \mathrm{C}^{\circ}$ yearly average temperature. Average of the annual temperature minimum is $-17 \mathrm{C}^{\circ}$, maximum reaches 34 $\mathrm{C}^{\circ}$. Average annual rainfall is measured $510-520 \mathrm{~mm}$, of which $310 \mathrm{~mm}$ falls during vegetation period. The area is traditionally of agricultural use, about $75 \%$ of the surface covered by croplands. Forest surface is under 5\% (Bulla 1962; Danszky, Rott 1964; Dövényi 2010; Marosi, Somogyi 1990). Before 1950' forests were uncommon to the region. At that time, intensive reforestation started with English oak ( $Q$. robur) (25\%), black locust (Robinia pseudo-acacia L.) (28\%) and Populus species 
(31\%) (Danszky, Rott 1964). The forest established in this period provides the base of current natural truffle habitats.

Site description method. In the study ecological characteristics of 20 truffle-producing natural habitats and data of a man-made truffle orchard were evaluated. Hungarian forest site description methodology was applied to determine the characteristics of natural habitats and the truffle orchard. Detailed site description included climate, micro-relief (elevation and orientation), hydrology and in-site soil description (soil type, type of mother rock, depth of organic layer and depth of soil layers based on 1,5 m deep soil-sampling holes). Besides these parameters soil colour (wet Munsell colour), granulometry, organic matter content (estimation based on soil colour), structure, compacted areas, quantity of roots, secondary soil formations, aggregations, estimate lime content and alkalinity for each soil layer were made. Laboratory chemical and physical analysis parameters were defined considering forest site description methodology (ÁESZ 2001, ÁESZ 2010, Babos et al. 1966; Buzás 1988; Buzás 1993; Szodfridt 1993) and summer truffle (T. aestivum) ecological requirements (Bratek 2005; Chevalier, Frochot 1997; Granetti et al. 2005; Morcillo et al. 2007; Wedén et al. 2004). Soil samples were collected from each soil layer, determined during site description. Examined parameters were: $\mathrm{pH}$ (both $\mathrm{H}_{2} \mathrm{O}$ and $\mathrm{KCl}$ ), lime content, organic matter content, soil conductivity (salt content), soil granulometry based on FAO Guidelines (1996). When necessary, further analysis was carried out in the case of saline and alkaline soils. In the article results of the laboratory analysis of the upper layer (A, A1, cca. 0-50 cm depth) were evaluated.

\section{RESULTS}

Site-description results. All the examined natural truffle habitats is covered by English oak $(Q$. robur) or mixed English oak-Turkey oak $(Q$. cerris $)$ forests. Field maple (Acer campestre L.), black locust (R. pseudo-acacia L.), field elm (Ulmus minor Mill.), Fraxinus spp., Russian olive (Elaeagnus angustifolia L.), common hackberry (Celtis occidentalis L.), Populus spp. and boxelder (Acer negundo L.) are also present in the forests. Elevation above sea level never exceeds $150 \mathrm{~m}$, micro-relief is flat in all the examined cases. Climate refers to forest steppe climatic category where annual rainfall less than 550-600 mm and annual average temperature is around $10.5 \mathrm{C}^{\circ}$. $68 \%$ of the sampled areas are affected by temporary presence of groundwater surplus, however, most common water management types of the soils were considered to be medium dry $(72 \%)$ or very dry $(18 \%)$. Water had heavily affected soil formation: gleysols $(63 \%)$ and water affected chernozem $(23 \%)$ are the most common soil types, in some cases solonchaks and solonetz soils occur (4.5 and 9\%, respectively). Mother rock is loess $(50 \%)$, sandy loess $(23 \%)$ or river sediment $(23 \%)$ in most of the cases.

Results of the laboratory analysis. Detailed granulometry of the examined soil samples resulted in the following textures: loam (40\%), clay loam (50\%) and clay $(9 \%)$. Only in one sampled area sand was present to define sandy loam soil. Main parameters of the chemical analysis are listed in Table 1. 
Table 1

Chemical parameters of the examined soil samples (Truff1-3: truffle orchard, Forest1-20: natural truffle habitats)

\begin{tabular}{|l|c|c|c|c|c|}
\hline Sample name & $\mathrm{pH}\left(\mathrm{H}_{2} \mathrm{O}\right)$ & $\mathrm{pH}(\mathrm{KCl})$ & Salt content \% & $\begin{array}{c}\text { Active } \\
\text { carbonate } \%\end{array}$ & $\begin{array}{c}\text { Organic } \\
\text { matter } \%\end{array}$ \\
\hline Truff1 & 7.2 & 6.7 & 0.04 & 0.0 & 2.6 \\
\hline Truff2 & 7.3 & 6.8 & 0.04 & 0.0 & 3.3 \\
\hline Truff3 & 7.1 & 6.6 & 0.04 & 0.0 & 3.7 \\
\hline Forest1 & 7.9 & 7.3 & 0.06 & 0.0 & 3.1 \\
\hline Forest2 & 7.3 & 6.7 & 0.08 & 0.0 & 3.2 \\
\hline Forest3 & 7.9 & 7.3 & 0.02 & 10.0 & 3.1 \\
\hline Forest4 & 7.9 & 7.3 & 0.02 & 8.0 & 5.0 \\
\hline Forest5 & 9.4 & 8.5 & 0.14 & 8.0 & 0.7 \\
\hline Forest6 & 7.7 & 7.2 & 0.04 & 9.0 & 3.8 \\
\hline Forest7 & 7.5 & 7.3 & 0.06 & 6.0 & 4.3 \\
\hline Forest8 & 8.3 & 7.2 & 0.21 & 3.0 & 3.6 \\
\hline Forest9 & 7.9 & 7.5 & 0.02 & 11.0 & 4.7 \\
\hline Forest10 & 7.9 & 7.4 & 0.03 & 19.0 & 4.3 \\
\hline Forest11 & 7.9 & 7.3 & 0.07 & 7.0 & 3.9 \\
\hline Forest12 & 7.7 & 7.1 & 0.03 & 1.0 & 3.3 \\
\hline Forest13 & 7.9 & 7.4 & 0.03 & 8.0 & 3.6 \\
\hline Forest14 & 7.9 & 7.4 & 0.01 & 2.0 & 2.2 \\
\hline Forest15 & 7.8 & 7.3 & 0.01 & 1.0 & 3.3 \\
\hline Forest16 & 6.1 & 5.4 & 0.01 & 0.0 & 4.3 \\
\hline Forest17 & 7.7 & 7.0 & 0.02 & 1.0 & 5.6 \\
\hline Forest18 & 6.4 & 5.5 & 0.01 & 0.0 & 2.8 \\
\hline Forest19 & 5.9 & 5.2 & 0.01 & 0.0 & 2.8 \\
\hline Forest20 & 7.1 & 6.3 & 0.00 & 0.0 & 3.8 \\
\hline
\end{tabular}

\section{DISCUSSION}

The climate of the examined area well fits in the requirement range of the species; however, for example, annual rainfall of Jászság is resulted to be more close to the annual precipitation of drier Gotland, Sweden $(514 \mathrm{~mm})$ (Wedén et al. 2004) and Copenhagen, Denmark (525 mm) (Hall et al. 2007) than those of traditional French truffle producing regions ( $727 \mathrm{~mm}$ on average) (Hall et al. 2007) or those of newly re-discovered German habitats $(825 \mathrm{~mm}$ ) (Stobbe et al. 2012). Similar to our research area, literature cites T. aestivum habitats of low elevation in most of the cases (Sweden, Denmark, UK, Switzerland, France, Croatia, and New-Zealand), only some Italian areas and Spanish results occur in hilly regions (Hall et al. 2007). Although hydrology and water management play an important role in T. aestivum production, data in the topic is scarce. Our study revealed that T. aestivum can occur on sites considered to be medium dry or dry, however, temporal water cover and soil texture (loam, clay loam and clay) can compensate together the problem of dryer summer periods. Soil texture can play an important role of counterbalancing dry and hot summers and this could be the explanation for more heavy soils in the research area compared to loam-sandy loam soils of Spain (Morcillo et al. 2007) or Sweden (Wedén et al. 2004). French samples (Chevalier, Frochot 1997) show more variance considering soil texture while Italian results (Granetti et al. 2005) proved to be the closest to the soil of the study area. Soil types are rarely determined in the 
Table 2

Main parameters of the examined soil samples compared to soil requirements of summer truffle (T. aestivum) (Bratek 2005; Chevalier, Frochot 1997; Granetti et al. 2005;

Morcillo et al. 2007; Wedén et al. 2004)

\begin{tabular}{|l|c|c|c|}
\hline $\begin{array}{c}\text { Literature data compared to examined sites } \\
\text { (min-max) }\end{array}$ & $\mathrm{pH}\left(\mathrm{H}_{2} \mathrm{O}\right)$ & $\begin{array}{c}\text { Active } \\
\text { carbonate }(\%)\end{array}$ & $\begin{array}{c}\text { Organic matter } \\
(\%)\end{array}$ \\
\hline Italian sites (Granetti et al. 2005) & $7.0-7.87$ & $0.9-20$ & $11-14$ \\
\hline Spanish sites (Morcillo et al. 2007) & $7.16-8.45$ & $0-71.43$ & $2.98-23.52$ \\
\hline Swedish sites (Wedén et al. 2004) & $6.8-7.9$ & $0.1-10.5$ & $6.0-21.2$ \\
\hline French sites (Chevalier, Frochot 1997) & $7.1-8.0$ & $0.4-52.0$ & $4.4-21.1$ \\
\hline Hungarian sites (Bratek 2005) & $6.1-7.4$ & $1-39$ & $3.1-9.1$ \\
\hline Results of the study area & $\mathbf{5 . 9 - 9 . 4}$ & $\mathbf{0 - 1 9}$ & $\mathbf{0 . 7 - 5 . 6}$ \\
\hline
\end{tabular}

literature in connection with T. aestivum. Chevalier, Frochot (1997) solely mention rendzina and luvisol types as suitable for the truffle compared to our findings where mainly gleysols and water affected chernozems occur, however, appearance of solonchaks and solonetz and also the presence water soluble salt in some quantities in two samples $(0.21 \%$ and $0.14 \%)$ indicates a certain tolerance toward lightly saline soils, previously not reported in literature. Main chemical parameters of the soil of examined habitats agree on earlier findings (Tab. 2). Considering $\mathrm{pH}$, except the abovementioned two saline soils, results fall within the previously indicated range.

Presence of active carbonate in the studied soils resulted very variable, ranging from 0 to $19 \%$ in the upper layer; carbonate-free soil samples of upper soil layers were present in cca. $40 \%$ of the examined cases, however, deeper soil layers (A1, A2, $\mathrm{AC}$, etc.) counterbalanced lime-free upper soil layer in all the cases (data not shown). In water-affected chernozems, slight dissolution of active carbonate resulted in lower carbonate content of the upper layer of the soil but limited decalcification due to low annual precipitation and the soil-mixing effect of rich edaphic fauna can be traced. In the case of gleysols, modest decalcification also results in the presence of carbonates in the upper layers of the soil. Due to the intensive evaporation of soil humidity in solonchaks and solonetz soils, water is moving upward and carries water-soluble salts, including less soluble carbonates which easily precipitate close to the surface. Limerich mother rock (loess, sandy loess or river sediment) also plays an important role in the high carbonate content of the examined soils (Stefanovits et al. 1999).

We found generally lower organic matter content than that of literature mentions, especially compared to Italian habitats, however, differences in organic matter due to distinct measurement methodology cannot be excluded.

\section{CONCLUSION}

Our findings generally supported the conception of the ecological demand of T. aestivum and some of the results even widened the tolerance of the species towards certain environmental conditions. 


\section{REFERENCES}

ÁESZ (Állami Erdészeti Szolgálat) 2001. Erdőtervezési útmutató, Állami Erdészeti Szolgálat Budapest. ÁESZ (Állami Erdészeti Szolgálat) 2010. Erdőrendezési útmutató, Termőhely felvétel kódjegyzéke és mellékletei. Kivonat. Állami Erdészeti Szolgálat, Budapest.

Babos I., Horváthné Proszt S., Járó Z., Király L., Szodfridt I., Tóth B. 1966. Erdészeti termőhelyfeltárás és térképezés. Akadémiai Kiadó, Budapest.

Bratek Z. 2008. Mycorrhizal Research Applied to Experiences in Plantations of Mycorrhizal Mushrooms, Especially in Central Europe. Proceedings of the Sixth International Conference on Mushroom Biology and Mushroom Products, Bonn: 272-286.

Bratek Z. 2005. A Tuber aestivum Kárpát-medencei termőhelyei (In:) G. Chevalier, H. Frochot, Z. Bratek (eds). Az európai fekete szarvasgomba (Burgundi szarvasgomba - Tuber uncinatum Chatin). Első Magyar Szarvasgombász Egyesület, Budapest.

Bulla B. 1962. Magyarország természeti földrajza. Tankönyvkiadó, Budapest.

Buzás I. (ed.) 1988. Talaj- és agrokémiai vizsgálati módszerkönyv 2. A talajok fizikai-kémiai és kémiai vizsgálati módszerei. Mezőgazdasági Kiadó, Budapest.

Buzás I. (ed.) 1993. Talaj- és agrokémiai vizsgálati módszerkönyv 1. A talaj fizikai, vízgazdálkodási és ásványtani vizsgálata. INDA 4231 Kiadó, Budapest.

Ceruti A., Fontana A., Nosenzo C. 2003. Le specie del genere Tuber. Una revisione storica. Museo Regionale di Scienze Naturali, Torino.

Chevalier G., Frochot H. 1997. La Truffe de Bourgogne (Tuber uncinatum Chatin). Éditions Pétrarque, Levallois-Perret Cedex.

Danszky I., Rott, F. (eds). 1964. Magyarország erdőgazdasági tájainak erdőfelújítási, erdőtelepítési irányelvei és eljárásai. Általános irányelvek. Erdő- és termőhelytípus térképezés, Budapest.

Dövényi Z. (ed.) 2010. Magyarország kistájainak katasztere. MTA Földrajztudományi Kutató Intézet, Budapest.

Food and Agriculture Organization of the United Nations 2006. Guidelines for soil description, Fourth Edition, Rome.

Gógán A. Cs., Bratek Z., Dimény J. 2007a. Las trufas en Hungría. (In:) S.R. Domenech (ed.). Truficultura: Fundamentos y técnicas, Ediciones Mundi-Prensa, Madrid.

Gógán A. Cs., Bratek Z., Dimény J. 2007b. A new tool for rural development: truffle cultivation, Cereal Research Communications 35 (2): 413-417.

Granetti B., De Angelis A., Materozzi G. 2005. Umbria terra di tartufi, Gruppo Micologico Ternano, Terni.

Hall I.R., Brown G. T., Zambonelli A. 2007. Taming the truffle. Timber Press, Portland.

Marosi S., Somogyi S. (eds) 1990. Magyarország kistájainak katasztere. MTA Földrajztudományi Kutató Intézet, Budapest.

Morcillo M., Moreno B., Pulido E., Sánchez M. 2007. Manual de truficultura Andaluza. Ed. Gypaetus y Consejería de Medio Ambiente. Junta de Andalucía.

Stefanovits P., Filep Gy., Füleky Gy. 1999. Talajtan. Mezőgazda Kiadó, Budapest.

Stobbe U, Büntgen U., Sproll, L., Tegel W., Egli S. 2012. Spatial distribution and ecological variation of re-discovered German truffle habitats. Fungal Ecology 5 (5): 591-599.

Szodfridt I. 1993. Erdészeti termőhelyismeret-tan. Mezőgazda Kiadó, Budapest.

Tulasne Ch. 1851. Fungi hypogaei. Apud Friedrich Klincksieck, Paris.

Weden C., Chevalier G., Danell E. 2004. Tuber aestivum (syn. T. uncinatum) biotopes and their history on Gotland. Sweden Mycological Research 108: 304-310.

Wedén CH., Danell E. 2001. Tuber aestivum uncinatum in Sweden. Actes du Ve Congrès International, Science et Culture de la Truffe et des autres Champignons Hypoges Comestibles. 4 au 6 mars 1999, Aix-en-Provence, France, Federation Française des Trufficulteurs p. 4.247. 